Acta Universitatis Wratislaviensis No 3799

PRAWO CCCXXIV

Wrocław 2017

DOI: $10.19195 / 0524-4544.324 .11$

ŁUKASZ BASZAK

Uniwersytet Wrocławski

baszak.lukasz@wp.pl

\title{
Odwołanie darowizny w polskim kodeksie zobowiązań z 1933 r.
}

\section{Wstęp}

Kodeks zobowiązań (k.z.) wprowadzony został w życie na mocy rozporządzenia Prezydenta Rzeczypospolitej z dnia 27 października 1933 r. (Dz.U. RP Nr 82, poz. 598 i sprost. Dz.U. RP 1934, Nr 54, poz. 492 ze. zm. oraz Dz.U. RP Nr 82, poz. 599 i sprost. Dz.U. RP 1934, Nr 54, poz. 492 ze zm.) z mocą obowiązującą od 1 lipca 1934 r. Głównymi twórcami kodeksu byli prof. Ernest Till ze Lwowa, jego uczeń Roman Longchamps de Berier ${ }^{1}$ — obaj pozostający w kręgu nauki austriackiej i niemieckiej — oraz adwokat dr Ludwik Domański z Warszawy wywodzący się z kręgu szkoły prawa francuskiego. Znaczny wkład w prace nad kodeksem zobowiązań miał również Henryk Konic, adwokat i zastępca profesora prawa cywilnego w Uniwersytecie Warszawskim ${ }^{2}$. Prace nad nowym prawem zobowiązań odbywały się w Komisji Kodyfikacyjnej przez ponad 10 lat. Przed uchwaleniem projektu kodeksu zobowiązań odpowiednie kolegia rozważyły projekty cząstkowe i inne materiały ${ }^{3}$. Polski kodeks zobowiązań powstał jako synteza ustawodawstw dzielnicowych, tj. francuskiego kodeksu

${ }^{1}$ Roman Longchamps de Berier po ogłoszeniu rozporządzenia prezydenta RP rozpoczął przygotowania Uzasadnienia, które ukazywało się częściami w latach 1934-1939. Zostało ono opracowane do art. 440 k.z. Stanowiło to jednak tylko jego prywatną pracę, chociaż publikowane było w oficjalnych wydawnictwach Komisji Kodyfikacyjnej. L. Górnicki, Prawo cywilne w pracach Komisji Kodyfikacyjnej Rzeczypospolitej Polskiej w latach 1919-1939, Wrocław 2000, s. 404.

${ }^{2}$ L. Górnicki, Zasada uspołecznienia pewnych stosunków umownych w kodeksie zobowiązań z 1933 roku, [w:] Zasady prawne w dziejach prawa publicznego i prywatnego, red. M. Podkowski, Wrocław 2015, s. 153-169.

${ }^{3}$ Szerzej na temat prac Komisji Kodyfikacyjnej nad prawem zobowiązań: L. Górnicki, Prawo cywilne..., s. 397-462. 
cywilnego z 1804 r. zwanego również kodeksem Napoleona (Code Napoleon, Code civil des Français - KN), austriackiego kodeksu cywilnego z 1811 r. (Allgemeines Bürgerliches Gesetzbuch - ABGB), niemieckiego kodeksu cywilnego z 1896 r. (Bürgerliches Gesetzbuch - BGB), tomu 10, części 1 rosyjskiego Zwodu Praw Cesarstwa Rosyjskiego z 1832 r. (Swod Zakonow Rossijskoj Imperii) oraz nowszych kodeksów i projektów, takich jak szwajcarskie prawo obligacyjne (Obligationenrecht — stanowiące piątą, wyodrębnioną redakcyjnie księgę kodeksu cywilnego z 1907 r., w wersji z 1911 r.), francusko-włoski projekt kodeksu zobowiązań i umów w wersji z roku 1927, a także projekt rosyjskiego prawa cywilnego w wersji z $1913 \mathrm{r}$. W ten sposób powstał oryginalny i nowoczesny polski kodeks zobowiązań, oparty na systemie mieszanym, tj. przedmiotowo-podmiotowym, którego cechą charakterystyczną była idea uspołecznienia ${ }^{4}$ prawa zobowiązań, będąca wynikiem kompromisu pomiędzy indywidualistycznym a społecznym prawem zobowiązań.

Kodeks zobowiązań opierał się jednak przeważnie na przepisach $\mathrm{BGB}^{5}$. Nie inaczej było w przypadku przepisów dotyczących darowizny, które znalazły się w art. 354-369 k.z. Przepisy te wzorowane były przeważnie na przepisach BGB oraz częściowo na przepisach szwajcarskiego prawa o zobowiązaniach z $1911 \mathrm{r}^{6}$ Podobnie unormowane zostały przepisy dotyczące odwołania darowizny, które znalazły się w art. 364-369 k.z.

\section{Odwołanie darowizny w razie zmiany stosunków majątkowych darczyńcy}

Kodeks zobowiązań przewidywał dla darczyńcy zupełne lub częściowe odwołanie darowizny. Nastąpić ono mogło z powodu zubożenia darczyńcy (art. 364 i 365 k.z.) oraz z powodu rażącej niewdzięczności, jakiej dopuścił się obdarowany względem darczyńcy ${ }^{7}$ (art. 366 i 367 k.z.). Na rozciągłość skutków odwołania darowizny miało wpływ to, czy darowizna w momencie odwołania była już wykonana, czy jeszcze nie ${ }^{8}$.

${ }^{4}$ Zob. L. Górnicki, Zasada uspołecznienia ..., s. 153-169.

${ }^{5}$ Zob. L. Górnicki, Prawo cywilne..., s. 397-462.

${ }^{6}$ L. Domański, Instytucje kodeksu zobowiązań. Komentarz teoretyczno-praktyczny. Część szczególna, Warszawa 1938, s. 138.

${ }^{7} \mathrm{SN}$ : „1) Strony mogą postanowić, że darczyńcy przysługuje prawo odwołania darowizny w przypadkach nieprzewidzianych w ustawie” (SN z dnia 30 marca 1938, C II 2544/37, „Przegląd Prawa i Administracji. Orzecznictwo" (dalej jako: PPiA.O) 1938, poz. 209).

${ }^{8}$ F. Zoll, Zobowiazania w zarysie wedlug polskiego kodeksu zobowiązań, Warszawa 1948, s. 329-330. 
W myśl art. 364 k.z. ${ }^{9}$ prawo odwołania darowizny przysługiwało jedynie co do darowizny jeszcze niewykonanej, czyli takiej, do której ważności potrzebne było oświadczenie darczyńcy sporządzone w formie aktu notarialnego (art. 358 § 1 k.z.). Darczyńca mógł odwołać darowiznę, jeżeli od momentu przyrzeczenia jego stosunki majątkowe uległy zmianie, powodując naruszenie własnego utrzymania (odpowiadającego jego stanowisku społecznemu) oraz naruszenie jego ustawowych obowiązków alimentacyjnych ${ }^{10}$. Z pojęcia odwołania wynika, że umowa darowizny przestawała obowiązywać z chwilą, gdy ono nastąpiło. Skutkowało to tym, że nawet w przypadku ewentualnej późniejszej poprawy stosunków majątkowych darczyńcy obdarowany nie miał już możliwości dochodzenia wykonania darowizny ${ }^{11}$.

Źródłem przepisu art. 364 k.z. był art. 72 projektu wstępnego polskiego prawa zobowiązań ${ }^{12}$, który wychodził z założenia, że darowizna nie powinna naruszać normalnej egzystencji darczyńcy i jego rodziny ${ }^{13}$. Wzorowany był on na $\S 519$ kodeksu cywilnego niemieckiego ${ }^{14}$ oraz art. 250 ust. 2 prawa obligacyjnego szwajcarskiego ${ }^{15}$.

W art. 364 k.z., w celu zabezpieczenia przez darczyńcę środków własnego utrzymania (odpowiadającego jego stanowisku społecznemu) oraz wykonania ciążących na nim ustawowych obowiązków alimentacyjnych, wprowadzono klauzulę rebus sic stantibus. Ustawodawca zezwolił darczyńcy odwołać darowiznę jeszcze niewykonaną, jeżeli od momentu przyrzeczenia darowizny jego stosunki majątkowe na tyle się zmieniły, że wykonanie darowizny wiązałoby się z uszczupleniem środków własne-

${ }^{9}$ Art. 364 k.z.: „Darczyńca może odwołać darowiznę jeszcze niewykonaną, jeżeli od chwili, kiedy ją był przyrzekł, jego stosunki majątkowe tak się zmieniły, że nie może wykonać darowizny bez uszczerbku dla własnego utrzymania, odpowiadającego jego stanowisku społecznemu, oraz bez uszczerbku dla ciążących na nim ustawowych obowiązków alimentacyjnych".

${ }^{10}$ Nie dotyczy to umownych obowiązków alimentacyjnych — zob.: J. Korzonek, I. Rosenblüth, Kodeks zobowiąań. Komentarz, t. 1, Kraków 1936, s. 931-932, oraz L. Peiper, Kodeks zobowiązań, Kraków 1934, s. 497.

11 J. Korzonek, I. Rosenblüth, op. cit., s. 931.

12 Projekt ten został opracowany przez prof. Ernesta Tilla oraz prof. Longchampsa de Berier będących członkami Komisji Kodyfikacyjnej. Większość kontraktów została opracowana wspólnie przez obydwu referentów. Umowa darowizny została opracowana po śmierci prof. Tilla przez prof. Longchampsa de Berier — zob. E. Till, R. Longchamps de Berier, Polskie prawo zobowiązań (część szczegółowa). Projekt wstępny z motywami, Lwów 1928.

13 Art. 72 projektu wstępnego: „Darczyńca nie jest obowiązany do wykonania darowizny, jeżeli od chwili oświadczenia, zawierającego przyrzeczenie darowizny, jego stosunki majątkowe tak się zmieniły, iż nie może dopełnić darowizny bez uszczerbku dla swego utrzymania, odpowiadającego jego stanowi, i dla dopełnienia ciążących na nim ustawowych obowiązków utrzymania krewnych i małżonka".

${ }^{14} \S 519$ BGB: „Darczyńca ma prawo odmówić wykonania przyrzeczenia, złożonego sposobem darmym, jeżeli w razie uwzględnienia innych jego zobowiązań nie może wypełnić go bez uszczerbku dla utrzymania, jakie na nim ciążą z mocy ustawy. W razie zbiegu roszczeń kilku obdarowanych, pierwszeństwo ma roszczenie, które powstało wcześniej”, [za:] L. Domański, op. cit., s. 175.

15 E. Till, R. Longchamps de Berier, op. cit., s. 118. 
go utrzymania, odpowiadającego jego stanowisku społecznemu ${ }^{16}$, oraz utrzymania członków rodziny ${ }^{17}$. Prawo odwołania przysługiwało od chwili, w której darczyńca uczynił przyrzeczenie darowizny, a bez znaczenia był moment, w którym obdarowany przyjął to przyrzeczenie ${ }^{18}$. Zmiana stosunków majątkowych, powodujących zubożenie darczyńcy, musiała zatem nastąpić po zaciągnięciu przez darczyńcę zobowiązania dokonania darowizny, a przed wykonaniem tego zobowiązania ${ }^{19}$. Jeżeli więc stan majątkowy darczyńcy w chwili przyrzeczenia darowizny nie pozwalał na jej wykonanie, darczyńca pozbawiony był prawa odwołania darowizny zgodnie z art. 364 k.z. ${ }^{20}$ Zmiana taka mogła nastąpić np. w wyniku utraty posady lub majątku przez darczyńcę już po złożeniu przyrzeczenia darowizny ${ }^{21}$. Mogła ona nastąpić bez winy lub choćby z winy darczyńcy, np. wskutek lekkomyślnych spekulacji, rozrzutności, pijaństwa itd. Inne rozwiązanie było przyjęte w niemieckim kodeksie cywilnym, gdzie wedle $§ 529$ odwołanie było niedopuszczalne, jeżeli darczyńca zmianę swych stosunków spowodował rozmyślnie lub przez swe rażące niedbalstwo ${ }^{22}$.

Z uzasadnienia do art. 364 k.z. wynikało, że o ile to było możliwe, odwołanie powinno się ograniczyć do takiej części przysporzenia, jaka jest potrzebna do wyrównania uszczerbku określonego w art. 364 k.z. ${ }^{23}$

W kodeksie nie została uregulowana kwestia odwołania darowizny jeszcze niewykonanej, w przypadku zawarcia umowy darowizny z kilkoma osobami równocześnie lub sukcesywnie. W doktrynie przyjęto zgodne stanowisko co do drugiego przypadku, a więc gdy darczyńca zawarł umowy darowizny z kilkoma osobami w różnym czasie. Wtedy odwołanie darowizny jeszcze niewykonanej mogło być wykonane kolejno, poczynając od umowy ostatnio zawartej ${ }^{24}$. Natomiast w razie zawarcia umowy darowizny z kilkoma osobami równocześnie, według Leona Peipera i Ludwika Domańskiego, odwołanie darowizny jeszcze niewykonanej powinno być zastosowane w stosunku do wszystkich obdarowanych ${ }^{25}$. Z kolei Ignacy

16 Według Leona Peipera na utrzymanie odpowiadającego darczyńcy stanowiska społecznego wpływają koszty odpowiedniego wyżywienia, mieszkania i odzienia oraz koszty leczenia i zaspokojenia potrzeb duchowych — zob. L. Peiper, op. cit., s. 497.

17 L. Domański, op. cit., s. 164.

18 J. Korzonek, I. Rosenblüth, op. cit., s. 932.

19 J. Namitkiewicz, Kodeks zobowiązań, Łódź 1949, s. 85.

20 J. Korzonek, I. Rosenblüth, op. cit., s. 932.

21 L. Domański, op. cit., s. 164.

22 L. Peiper, op. cit., s. 497. Odmiennego zdania był Jan Namitkiewicz, który uważał, że jeśli przyczyną zubożenia były okoliczności, za które darczyńca ponosił odpowiedzialność, w szczególności gdy zubożenie było spowodowane czynami nagannymi, nie miał on prawa do odwołania darowizny (op. cit., s. 85-86); podobne stanowisko zajmował Ludwik Domański (op. cit., s. 164).

23 R. Longchamps de Berier, Uzasadnienie projektu kodeksu zobowiazań, art. 294-369, t. 7, Warszawa 1937, s. 107. Swoje wątpliwości co do słuszności takiej interpretacji wyraził J. Namitkiewicz, op. cit., s. 85.

24 L. Domański, op. cit., s. 164; J. Korzonek, I. Rosenblüth, op. cit., s. 932-933; L. Peiper, op. cit., s. 497.

25 L. Domański, op. cit., s. 164; L. Peiper, op. cit., s. 933. 
Rosenblüth i Jan Korzonek dopuszczali możliwość wyboru przez darczyńcę, czy odwołanie dotyczyć miało wszystkich obdarowanych czy tylko niektórych z nich.

Jeżeli mimo odwołania darowizny wedle art. 364 k.z. obdarowany domagał się jej wykonania, twierdząc, że nie zachodzą warunki odwołania, to obowiązek udowodnienia zaistnienia tych warunków spoczywał na darczyńcy ${ }^{26}$.

Zrzeczenie się przez darczyńcę praw zawartych w art. 364 k.z. byłoby nieważne ze względu na cele społeczne ${ }^{27}$ i naruszenie praw osób trzecich ${ }^{28}$.

Ustawodawca w art. 365 k.z. ${ }^{29}$ uregulował również sytuację, gdy darczyńca popadnie w niedostatek, ale już po wykonaniu darowizny. Źródłem tego przepisu był art. 76 projektu wstępnego ${ }^{30}$, który wzorowany był na $\S 947$ kodeksu cywilnego austriackiego ${ }^{31}$. Twórcy kodeksu zobowiązań uznali rozwiązania przyjęte w tym zakresie w kodeksie Napoleona oraz w kodeksie cywilnym niemieckim za zbyt surowe dla obdarowanego. Kodeks cywilny niemiecki w $\S 528$ przyznawał darczyńcy prawo odwołania darowizny, o ile było to potrzebne do pokrycia jego utrzymania, odpowiadającego stanowi, i ciążących na nim ustawowych obowiązków alimentacyjnych i o ile obdarowany był jeszcze zbogacony. Z kolei kodeks Napoleona w tym przypadku przyznawał w art. 955 ust. 3 darczyńcy prawo odwołania darowizny w zupełności, ale tylko wówczas, gdy obdarowany odmówił darczyńcy, popadłemu w niedostatek, alimentów.

Dlatego za wzorem kodeksu cywilnego austriackiego nałożono na obdarowanego tylko obowiązek alimentacyjny w wysokości ustawowych odsetek od wartości zbogacenia ${ }^{32}$. Obdarowany mógł się jednak zwolnić od tego obowiązku przez

26 J. Korzonek, I. Rosenblüth, op. cit., s. 933.

27 Zob. L. Górnicki, Zasada uspołecznienia ..., s. 153-169.

${ }^{28}$ L. Peiper, op. cit., s. 498.

29 Art. 365 k.z.: „Jeżeli darczyńca popadnie w niedostatek po wykonaniu darowizny, obdarowany, o ile jeszcze zbogacony skutkiem darowizny, ma obowiązek dostarczać darczyńcy środków, których mu brakuje do utrzymania, odpowiadającego jego stanowisku społecznemu, i do dopełnienia ciążących na nim ustawowych obowiązków alimentacyjnych. Obdarowany nie jest obowiązany płacić z tego tytułu więcej, niż wynoszą ustawowe odsetki od wartości zbogacenia. Może się zwolnić od tego obowiązku, zwracając darczyńcy wartość zbogacenia, będącego następstwem darowizny".

${ }^{30}$ Art. 76 projektu wstępnego: „Jeśli darczyńca po wykonaniu darowizny popadnie w niedostatek, obdarzony, o ile jeszcze jest zbogacony skutkiem darowizny, obowiązany jest uzupełnić to, co darczyńcy brakuje do jego utrzymania, odpowiadającego jego stanowi, i do wypełnienia ciążących na nim ustawowych obowiązków utrzymania jego krewnych i małżonka, a to do wysokości prawnych odsetek od wartości zbogacenia w chwili jego uzupełnienia”.

31 § 947 ABGB: ,Jeżeli darujący po uczynieniu darowizny popadnie w taką nędzę, że zbywa mu na potrzebnym utrzymaniu, wówczas ma prawo żądać od obdarowanego, aby mu płacił corocznie ustawowe odsetki od darowanej sumy, o ile rzecz darowana lub jej wartość jeszcze istnieje i o ile darującemu zbywa na potrzebnym utrzymaniu, chyba że obdarowany znajduje się sam w równym niedostatku. Z pomiędzy większej liczby obdarowanych, wcześniej obdarowany wtedy tylko jest do tego obowiązany, jeżeli zasiłki później obdarowanych nie wystarczają do utrzymania”, [za:] L. Domański, op. cit., s. 163.

$32 \mathrm{SN}$ : „Obdarowany nie jest obowiązany płacić z tego tytułu więcej niż wynoszą odsetki ustawowe od wartości zbogacenia” (SN z dnia 14 września 1937, C II 651/37, „Nowy Kodeks Zobowiązań” 1938, s. 51), [za:] J. Namitkiewicz, op. cit., s. 86. 
zwrot wartości zbogacenia ${ }^{33}$, będącego następstwem darowizny ${ }^{34}$. Obowiązek obdarowanego trwał tak długo, jak długo był jeszcze zbogacony. Utrata zbogacenia miała miejsce również wtedy, gdy obdarowany wartość zbogacenia zużył lub utracił. Jeżeli jednak obdarowany utracił wartość zbogacenia w złej wierze lub gdy obdarowany powinien się był liczyć z obowiązkiem zwrotu, zwłaszcza po uzyskaniu wiadomości o popadnięciu darczyńcy w niedostatek, wtedy zwolnienie od zwrotu zbogacenia nie następowało ${ }^{35}$.

Roszczenie z art. 365 k.z. przysługiwało darczyńcy, gdy popadł w niedostatek ${ }^{36}$ po wykonaniu darowizny i brakowało mu środków do utrzymania odpowiadającego jego stanowisku społecznemu, po dopełnieniu ustawowych obowiązków alimentacyjnych. Jeśli zdarzyło się to przed wykonaniem darowizny, a darczyńca nie skorzystał z przepisu art. 364 k.z., to pozostawał w tym przypadku bez żadnych roszczeń wobec obdarowanego. W przypadku, gdy obdarowanych było więcej, stosowano te same zasady co w art. 364 k.z. ${ }^{37}$

Rozwiązania, jakie przyjęto w art. 365 k.z., miały być dla darczyńcy rekompensatą za cierpienie niedostatku skutkiem darowizny ${ }^{38}$. Dlatego dzięki przyznanemu roszczeniu miał on mieć zapewniony mniej więcej taki dochód z przedmiotu darowizny, jaki mógłby mieć, gdyby jej nie uczynił. Z kolei dla obdarowanego było to korzystne, ponieważ zobowiązanie alimentacyjne wygasało ze śmiercią darczyńcy ${ }^{39} \mathrm{i}$ istniało tylko pro futuro ${ }^{40}$. Nie było to zatem odwołanie darowizny, lecz udzielenie pomocy darczyńcy będącej wyrazem wdzięczności ze strony obdarowanego, co budziło wątpliwości co do umieszczenia tego przepisu w rozdziale o odwołaniu darowizny ${ }^{41}$.

${ }^{33}$ Nie był to więc zwrot przedmiotu darowizny w naturze, ani zwrot przysporzenia majątkowego, ani możliwość jednorazowej zapłaty wartości przedmiotu darowizny; tylko obdarowany miał prawo wyboru — zob. J. Korzonek, I. Rosenblüth, op. cit., s. 935-936; J. Namitkiewicz, op. cit., s. $86-87$.

${ }^{34}$ R. Longchamps de Berier, op. cit., s. 107-108.

35 J. Namitkiewicz, op. cit., s. 86-87.

${ }^{36}$ Jak w przypadku art. 364, możemy się spotkać w doktrynie z różną interpretacją tego przepisu, tj. według Peipera roszczenie przysługuje darczyńcy, nawet jeśli popadł on w niedostatek z własnej winy (op. cit., s. 498); odmienne stanowisko miał Namitkiewicz (op. cit., s. 85).

37 J. Korzonek, I. Rosenblüth, op. cit., s. 934-935.

38 E. Till, R. Longchamps de Berier, op. cit., s. 122.

39 Roszczenie to miało ściśle osobisty charakter, więc nie mogło być odstąpione i nie mogło przechodzić na spadkobierców (z wyjątkiem należności umownie lub prawomocnym wyrokiem przyznanych i to jedynie już wymagalnych), jednak w przypadku obdarowanego obowiązek zaspokojenia roszczenia darczyńcy przechodził na jego spadkobierców — zob. J. Korzonek, I. Rosenblüth, op. cit., s. 936; L. Domański, op. cit., s. 166.

${ }^{40}$ R. Longchamps de Berier, op. cit., s. 108.

${ }^{41}$ J. Namitkiewicz, op. cit., s. 86. 


\section{Odwołanie darowizny w razie niewdzięczności obdarowanego}

Zgodnie z treścią art. 366 k.z. ${ }^{42}$ darczyńca mógł odwołać darowiznę nawet już wykonaną z powodu rażącej niewdzięczności, jakiej dopuścił się względem niego obdarowany, zwłaszcza jeśli popełniony przez obdarowanego czyn stanowił przestępstwo albo ciężkie naruszenie obowiązków rodzinnych.

We wszystkich obowiązujących kodeksach porozbiorowych występowały przepisy normujące odwołanie darowizny z powodu niewdzięczności. Według KN (art. 955) przyczyną odwołania darowizny z powodu niewdzięczności było targnięcie się na życie darczyńcy oraz złe obchodzenie się, występki i obelgi, wszystko w ciężkim stopniu. Według ABGB (§ 948) była to ciężka niewdzięczność, tj. takie skrzywdzenie darczyńcy na ciele, czci, wolności lub majątku, które nadaje się do karno-sądowego ścigania. Z kolei BGB (§ 530) dopuszczał odwołanie darowizny z powodu ciężkiej niewdzięczności, która polegała na ciężkim uchybieniu względem darującego lub bliskiego członka jego rodziny. Natomiast według tomu 10, części 1 rosyjskiego Zwodu Praw Cesarstwa Rosyjskiego z 1832 r. (art. 974) przyczyną odwołania darowizny z powodu niewdzięczności był zamach na życie darującego, pobicie, groźby, fałszywe oskarżenie o przestępstwo oraz oczywiste nieuszanowanie. Twórcy kodeksu zobowiązań badali również rozwiązania przyjęte w kodeksie szwajcarskim, w którym przepisy art. 249 ust. 1 i 2 dopuszczały odwołanie darowizny z powodu ciężkiej zbrodni przeciw darczyńcy lub bliskim oraz ciężkiego naruszenia obowiązków familijno-prawnych wobec darczyńcy lub bliskich ${ }^{43}$.

Źródłem przepisu art. 366 k.z. był art. 77 projektu wstępnego ${ }^{44}$. Porównując projektowany przepis z ostatecznym brzmieniem art. 366 k.z., można zauważyć, że ustawodawca nie określił pojęcia rażącej niewdzięczności. Zdecydowano, że ustawa nie powinna taksatywnie wymieniać rodzajów niewdzięczności uzasadniających odwołanie, ze względu na wytworzony przez darowiznę stosunek etyczny między darczyńcą a obdarowanym. Uznano, że właśnie ze względu na ten wybitnie etyczny charakter tego stosunku należy pozostawić swobodę sędziemu w podejmowaniu decyzji ${ }^{45}$. Za rażącą niewdzięczność można było zatem uznać

42 Art. 366 k.z.: „Darczyńca może odwołać darowiznę, nawet już wykonaną, jeżeli obdarowany dopuścił się względem niego rażącej niewdzięczności, zwłaszcza przez popełnienie czynu, stanowiącego przestępstwo albo ciężkie naruszenie obowiązków rodzinnych".

43 R. Longchamps de Berier, op. cit., s. 108.

${ }^{44}$ Art. 77 projektu wstępnego: „Darczyńca może odwołać darowiznę, chociażby już wykonaną, jeżeli obdarzony dopuści się wobec niego lub jego bliskich ciężkiej niewdzięczności przez uchybienia, nadające się do karno-sądowego dochodzenia albo przedstawiające się, jako naruszenia obowiązków familijno-prawnych".

${ }^{45}$ R. Longchamps de Berier, op. cit., s. 110-111. 
każdy czyn lub szereg czynów popełnionych przez obdarowanego ${ }^{46}$ rozmyślnie, aby wyrządzić krzywdę moralną lub materialną darczyńcy ${ }^{47}$. Jednak aby ułatwić zadanie sędziemu, wymieniono przykładowe fakty uzasadniające odwołanie z powodu rażącej niewdzięczności. Były to czyny stanowiące przestępstwo ${ }^{48}$ oraz naruszenie obowiązków rodzinnych ${ }^{49}$. Przestępstwo mogło być popełnione nie tylko na osobie lub mieniu darczyńcy, ale także na osobie lub mieniu członków jego rodziny ${ }^{50}$. Jednak nie każdy czyn stanowiący przestępstwo, biorąc pod uwagę pewne okoliczności, musiał być poczytany za rażącą niewdzięczność. Decydować miał o tym sędzia, kładąc nacisk na stopień niewdzięczności ${ }^{51}$, a dowód popełnienia przestępstwa mógł być przeprowadzony przed sądem cywilnym, bez uprzedniego wszczęcia i zakończenia procesu karnego ${ }^{52}$. Z kolei za ciężkie naruszenie obowiązków rodzinnych uznawano np. uporczywe uchylanie się obdarowanego od dostarczania środków utrzymania dla darczyńcy wynikających z ustawowego obowiązku, nierząd z członkami rodziny darczyńcy, nieudzielenie darczyńcy pomocy w niebezpieczeństwie dla jego życia, zdrowia lub mienia ${ }^{53}$.

W orzecznictwie dotyczącym art. 366 k.z. najwięcej miejsca poświęcono określeniu pojęcia rażącej niewdzięczności, biorąc przede wszystkim pod uwagę okoliczności popełnienia czynu wyrządzającego szkodę darczyńcy, tj. świadomość, nieprzyjazny zamiar, prowokację itp. ${ }^{54}$

46 SN: „Nie stanowią podstawy do odwołania darowizny zniewagi, których wobec darczyńcy dopuszcza się mąż obdarowanej” (SN z dnia 21 grudnia 1937, C II 1613/37, „Nowy Kodeks Zobowiązań" 1938, s. 161), [za:] J. Namitkiewicz, op. cit., s. 88-89.

${ }^{47}$ L. Domański, op. cit., s. 167; L. Peiper, op. cit., s. 503; J. Korzonek, I. Rosenblüth, op. cit., s. 937.

48 Za czyn stanowiący przestępstwo Peiper uznawał zbrodnię lub występek, a nawet wykroczenia (op. cit., s. 503).

49 R. Longchamps de Berier, op. cit., s. 110-111.

${ }^{50}$ L. Domański, op. cit., s. 167.

${ }^{51}$ R. Longchamps de Berier, op. cit., s. 110-111; J. Korzonek, I. Rosenblüth, op. cit., s. 937-938.

${ }^{52}$ L. Domański, op. cit., s. 167-168; J. Korzonek, I. Rosenblüth, op. cit., s. 938.

${ }^{53}$ L. Domański, op. cit., s. 167-168; L. Peiper, op. cit., s. 503.

${ }^{54}$ Wybrane orzeczenia SN: „Według ustawy przez ciężką niewdzięczność należy rozumieć takie naruszenie ciała, czci, wolności lub majątku, że przeciwko naruszającemu można wdrożyć postępowanie z ustawy karnej z urzędu lub na żądanie pokrzywdzonego. Nie każdy atoli czyn karalny, a nawet ukarany, musi mieć znamiona niewdzięczności. $\mathrm{Z}$ istoty pojęcia niewdzięczności wynika konieczność świadomego i celowego działania, aby ukrzywdzić darczyńcę i świadomość, że się popełnia niewdzięczność. Nie zachodzi jednak niewdzięczność, mimo odpowiedzialności karnej, w razie prowokacji ze strony darczyńcy. Jeżeli według ustaleń powód sprowokował pozwanego przy każdej sposobności, aby przez to wywołać u pozwanego reakcję i stworzyć podstawę do odwołania darowizny, a pozwany na prowokację reagował, to nie można mówić o świadomym i celowym działaniu pozwanego, któreby nosiło znamiona ciężkiej niewdzięczności” (SN z dnia 6 września 1937, C II 580/37, „Głos Adwokatów” 1938, z. 4, s. 131); „Wynika z pojęcia niewdzięczności, że podpada pod nią jedynie taka czynność obdarowanego, która była skierowana przeciwko darczyńcy ze świadomością i w nieprzyjaznym zamiarze, że natomiast wyłączone są krzywdy niezamierzone, popełnione w rozdrażnieniu czy uniesieniu, wywołanym zachowaniem się czy działaniem darczyńcy” (SN z dnia 
W art. 367 k.z. ${ }^{55}$ zawarto kolejne przepisy dotyczące prawa odwołania darowizny. Wedle $\S 1$ art. 367 k.z. ${ }^{56}$ darowizna nie mogła być odwołana z powodu niewdzięczności, jeżeli darczyńca przebaczył obdarowanemu, a także po śmierci obdarowanego. Źródłem tego przepisu był art. 79 projektu wstępnego ${ }^{57}$. W związku z tym, że prawo odwołania darowizny z powodu niewdzięczności było uzasadnione względami etycznymi, przyjęto, że przebaczenie ze strony darczyńcy naprawia stosunek etyczny między darczyńcą a obdarowanym, a prawo odwołania wygasa po przebaczeniu. Zdecydowano się zatem na wyraźne wspomnienie o przebaczeniu, jak to miało miejsce w kodeksie cywilnym niemieckim i austriackim ${ }^{58}$. Za kodeksem Napoleona, kodeksem cywilnym niemieckim oraz szwajcarskim kodeksem zobowiązań niedopuszczalne było odwołanie wobec spadkobierców obdarowanego ${ }^{59}$. Jeżeli jednak odwołanie darowizny nastąpiło przed śmiercią obdarowanego, skutki dokonanego odwołania obciążałyby również jego spadkobierców ${ }^{60}$. Niedopuszczalne było zrzeczenie się prawa odwołania darowizny z powodu niewdzięczności,

14 grudnia 1937, C II 1542/37, „Przegląd Notarialny” 1938, nr 7-8), [za:] F. Zoll, op. cit., s. 330; „Nie stanowi podstawy odwołania darowizny cudzołóstwo popełniane przez obdarowanego za zgodą żony, która go obdarowała” (SN z dnia 10 lutego 1938, C II 2054/37, OSP 517/1938); „Sam fakt pobicia, względnie zniewagi darczyńcy przez obdarowanego, jakkolwiek stwierdzony wyrokiem karnym, nie jest przyczyną odwołania darowizny, jeśli wywołany został skutkiem prowokacji, a nie był wypływem świadomego nieprzyjaznego zamiaru” (SN z dnia 14 grudnia 1937, C II 1542/37, „Nowa Palestra” 1938, nr 6, s. 230), [za:] F. Zoll, op. cit., s. 331; „Pod pojęcie niewdzięczności w rozumieniu art. 366 k.z. podpada jedynie taka czynność obdarowanego, która skierowana była przeciwko darczyńcy ze świadomością i w nieprzyjaznym zamiarze, wyłączone więc są krzywdy niezamierzone, popełnione w uniesieniu czy rozdrażnieniu, wywołanym zachowaniem się czy działaniem darczyńcy" (SN z dnia 2 marca 1948, KrC 42/48, „Państwo i Prawo” 1948, z. 7, s. 136); „Uzasadnione jest odwołanie przez darczyńcę darowizny na tej podstawie, że obdarowani, córka jego i zięć, wpisali się na niemiecką listę narodową, przez co okryli się hańbą i dopuścili się w ten sposób ciężkiego naruszenia obowiązków rodzinnych” (SN z dnia 21 stycznia 1948, C I 773/47, „Państwo i Prawo” 1948, z. 5-6, s. 177).

55 Art. 367: „§ 1. Darowizna nie może być odwołana z powodu niewdzięczności, jeżeli darczyńca przebaczył obdarowanemu, jak również po śmierci obdarowanego.

$\S 2$. Prawo odwołania darowizny z powodu niewdzięczności służy spadkobiercom darczyńcy, jeżeli istniało jeszcze w chwili jego śmierci, albo gdy powstało skutkiem tego, że obdarowany rozmyślnie pozbawił darczyńcę życia.

$\S 3$. Prawo odwołania darowizny z powodu niewdzięczności wygasa z upływem roku od chwili, kiedy uprawniony do odwołania dowiedział się o niewdzięczności obdarowanego".

56 Źródłem przepisu $\S 1$ art. 367 k.z. był ust. 2 art. 79 projektu głównego: „odwołanie jest wykluczone, jeżeli darczyńca przebaczył obdarzonemu oraz po śmierci obdarzonego”.

57 Art. 79 projektu wstępnego: „Odwołanie darowizny z powodu niewdzięczności może nastąpić tylko w ciągu roku od chwili, w której darczyńca dowiedział się o niewdzięczności obdarzonego, a jeżeli zmarł przed tem, od chwili jego śmierci. Odwołanie jest wykluczone, jeżeli darczyńca przebaczył obdarzonemu oraz po śmierci obdarzonego".

${ }^{58}$ Inne rozwiązania występowały w prawie francuskim i szwajcarskim — zob. R. Longchamps de Berier, op. cit., s. 111-112.

59 Ibidem, s. 111.

${ }^{60}$ L. Domański, op. cit., s. 168; J. Korzonek, I. Rosenblüth, op. cit., s. 938; J. Namitkiewicz, op. cit., s. 86. 
co uznawano za przeciwne dobrym obyczajom ${ }^{61}$. Gdyby jednak zrzeczenie się prawa odwołania darowizny nastąpiło po dopuszczeniu się przez obdarowanego czynu niewdzięczności, traktowano to wtedy na równi z przebaczeniem ${ }^{62}$.

Źródłem przepisu $\S 2$ art. 367 k.z. był art. 78 projektu wstępnego ${ }^{63}$. Wzorowany był on w głównej mierze na art. 251 szwajcarskiego kodeksu cywilnego ${ }^{64}$. W myśl $\S 2$ art. 367 k.z. prawo odwołania darowizny z powodu niewdzięczności służyło spadkobiercom darczyńcy, jeżeli istniało jeszcze w chwili jego śmierci, tj. nie nastąpiło wcześniej przebaczenie i nie upłynął rok od czasu, gdy darczyńca dowiedział się o niewdzięczności. Niewdzięczność obdarowanego stanowiła według ustawodawcy czyn niemoralny, dlatego też prawo odwołania darowizny z powodu niewdzięczności obdarowanego względem darczyńcy przysługiwało spadkobiercom darczyńcy, nawet gdyby darczyńca zmarł, nie dowiedziawszy się wcześniej o niewdzięczności obdarowanego. Prawo odwołania darowizny z powodu niewdzięczności przysługiwało spadkobiercom ustawowym, a z testamentowych tylko zapisobiorcom ogólnym lub pod tytułem ogólnym, z wyłączeniem zapisobiorców szczególnych.

Wedle $\S 2$ art. 367 k.z. prawo odwołania darowizny przysługiwało spadkobiercom również $\mathrm{w}$ przypadku, gdy obdarowany rozmyślnie pozbawił życia darczyńcę. Prawo odwołania $\mathrm{w}$ tym przypadku było nieskuteczne, jeżeli darczyńca przebaczył obdarowanemu za swego życia lub nie dopuścił do bezskutecznego upływu rocznego terminu zawitego, przewidzianego w $\S 3$ art. 367 k.z. Za rozmyślne pozbawienie darczyńcy życia rozumiano świadome nastawanie obdarowanego na życie darczyńcy, którego skutkiem była śmierć. W przypadku, gdyby obdarowany z takim zamiarem dopuścił się uszkodzenia ciała darczyńcy lub wywołał rozstrój zdrowia, a skutkowałoby to śmiercią darczyńcy dopiero po pewnym czasie, prawo odwołania powstawało z chwila popełnienia przez obdarowanego czynu występnego i przechodziło na spadkobierców z chwilą śmierci darczyńcy. Spadkobiercy mogli to prawo wykonać łącznie lub każdy z osobna. Poza tym każdy spadkobierca mógł żądać wydania części odzyskanego przedmiotu darowizny, nawet jeśli sam prawa odwołania darowizny nie wykonał ${ }^{65}$.

${ }^{61}$ Art. 56 k.z.: „§ 1. Umowy treści niemożliwej do wykonania oraz umowy sprzeczne z porządkiem publicznym, ustawą lub dobremi obyczajami, są nieważne. § 2. Jeżeli wadliwości tego rodzaju dotyczą tylko niektórych postanowień umowy, inne postanowienia pozostają w mocy, chyba, że przypuszczać należy, iż bez postanowień dotkniętych nieważnością, strony nie byłyby zawarły umowy”.

62 L. Domański, op. cit., s. 168.

${ }^{63}$ Art. 78 projektu wstępnego: ,prawo odwołania darowizny z powodu niewdzięczności przechodzi na dziedziców darczyńcy, jeżeli w chwili jego śmierci jeszcze istniało lub powstało skutkiem zabicia darczyńcy przez obdarzonego".

${ }^{64}$ Art. 251 szwajcarskiego prawa o zobowiązaniach: „Odwołanie (darowizny) może nastąpić w ciągu roku, licząc od dnia, w którym darczyńca dowiedział się o przyczynie odwołania. Jeżeli darczyńca zmarł przed upływem roku, jego prawo przechodzi na spadkobierców, którzy mogą z niego skorzystać do końca tego okresu czasu. Spadkobiercy mogą odwołać darowiznę, jeżeli obdarowany rozmyślnie lub w inny sposób niedozwolony przyczynił się do śmierci darczyńcy lub przeszkodził mu w skorzystaniu z prawa odwołania", [za:] L. Domański, op. cit., s. 168.

${ }^{65}$ Ibidem, s. 170. 
Prawo odwołania darowizny z powodu niewdzięczności, zgodnie z $§ 3$ art. 367 k.z., wygasało z upływem roku od chwili, kiedy uprawniony do odwołania dowiedział się o niewdzięczności obdarowanego. Wyznaczono więc za kodeksem Napoleona oraz kodeksem cywilnym niemieckim roczny termin zawity do odwołania. Ustawodawca ze względu na osobisty charakter darowizny wyszedł z założenia, że jeżeli darczyńca przez dłuższy czas od dowiedzenia się o niewdzięczności nie odwołuje darowizny, można przypuszczać, że nie poczuł się dotknięty niewdzięcznością lub przebaczył obdarowanemu. Ważnym powodem wyznaczenia czasu odwołalności było wyeliminowanie ewentualnej niepewności obdarowanego, który naprawił swój błąd, a nie uzyskał wyraźnego przebaczenia od darczyńcy. Skutkować to mogło niepewnością z punktu widzenia gospodarczego, co ustawodawca uznał za niepożądane $^{66}$. Źródłem tego przepisu był ust. 1 art. 79 projektu wstępnego ${ }^{67}$. Porównując obydwa przepisy, można zauważyć różnicę polegającą na tym, że według k.z. prawo odwołania darowizny z powodu niewdzięczności wygasało z upływem roku zarówno dla darczyńcy, jak i dla jego spadkobierców, licząc od chwili, w której darczyńca lub jego spadkobierca dowiedzieli się o niewdzięczności obdarowanego ${ }^{68}$. Termin roczny stosowano w stosunku do spadkobierców, gdy darczyńca nie odwoławszy darowizny, zmarł przed upływem roku od faktu niewdzięczności, jak i wtedy, gdy prawo odwołania powstało na rzecz spadkobierców w razie pozbawienia życia darczyńcy $^{69}$. Było to rozwiązanie, którego nie było w kodeksach pozaborowych ${ }^{70}$.

\section{Treść i forma odwołania darowizny oraz zwrot przedmiotu darowizny}

Według art. 368 k.z. ${ }^{71}$ odwołanie wykonywało się przez oświadczenie na piśmie skierowanym do obdarowanego, a zwrot przedmiotu darowizny następował według przepisów o niesłusznym zbogaceniu ${ }^{72}$. Źródłem przepisów tego artykułu

${ }^{66}$ R. Longchamps de Berier, op. cit., s. 114.

${ }^{67}$ Art. 79 ust. 1 projektu wstępnego: „Odwołanie darowizny z powodu niewdzięczności może nastąpić tylko w ciągu roku od chwili, w której darczyńca dowiedział się o niewdzięczności obdarzonego, a jeżeli zmarł przed tym, od chwili jego śmierci”.

${ }^{68}$ L. Domański, op. cit., s. 170.

69 J. Namitkiewicz, op. cit., s. 92.

${ }^{70}$ Szerzej R. Longchamps de Berier, op. cit., s. 114-115.

71 Art. 368 k.z.: „§ 1. Odwołanie wykonywa się przez oświadczenie na piśmie skierowane do obdarowanego. $\S 2$. Zwrot przedmiotu darowizny następuje według przepisów o niesłusznym zbogaceniu. Od chwili popełnienia czynu uzasadniającego odwołanie obdarowanego uważa się za będącego w złej wierze".

$72 \mathrm{SN}$ : ,2) Odwołanie darowizny przez wniesienie pozwu zawiera w sobie wymagane przez przepis art. 368 § 1 k.z. oświadczenie na piśmie" (SN z dnia 30 marca 1938, C II 2544/37, PPiA.O 1938, poz. 209, s. 340-341). 
był art. 80 projektu wstępnego ${ }^{73}$. Ostatecznie konferencja międzyministerialna dokonała zmian w stosunku do pierwotnego brzmienia tego artykułu poprzez zamieszczenie postanowienia o pisemnej formie oświadczenia, zwracając uwagę na wyjątkowy charakter darowizny ${ }^{74}$. Niezachowanie formy pisemnej skutkowało niedopuszczalnością, bez zgody stron, dowodu ze świadków (art. 110 k.z.), z przesłuchania stron i domniemania (art. 323 k.p.c. ${ }^{75}$. Kodeks zobowiązań uznawał za wystarczające pozasądowe oświadczenie ${ }^{76}$. Treść tego oświadczenia mogła być różna. Najistotniejsze było to, aby wynikała z niej wola odwołania darowizny przez darczyńcę lub jego spadkobierców z powodu rażącej niewdzięczności. Oświadczenie powinno było jednak zawierać wskazanie czynu obdarowanego świadczące o jego rażącej niewdzięczności.

Wykonanie odwołania darowizny poprzez pisemne oświadczenie nie stanowiło o skuteczności odwołania. Następowała ona w momencie doręczenia pisma do obdarowanego (art. 30 k.z.). Odwołanie stawało się bezskuteczne, gdy obdarowany zmarł przed doręczeniem mu pisma albo upłynął roczny termin od dowiedzenia się uprawnionego do odwołania o niewdzięczności obdarowanego ${ }^{77}$. Gdyby darowizna nie została wykonana przed odwołaniem darowizny, wtedy złożenie oświadczenia wystarczało do zwolnienia darczyńcy z obowiązku dokonania darowizny na rzecz obdarowanego. Jeżeli obdarowany twierdził, że nie było rażącej niewdzięczności, wtedy musiał wytoczyć powództwo przeciwko darczyńcy lub jego spadkobiercom. Jeżeli jednak umowa darowizny została wykonana, obdarowany mógł żądać uznania odwołania za bezzasadne ${ }^{78}$ lub żądać zasądzenia przedmiotu darowizny. Natomiast darczyńca musiał wytoczyć powództwo o zwrot przedmiotu darowizny, gdyby obdarowany dobrowolnie go nie zwróci7 ${ }^{79}$. Zgodnie z $\S 2$ art. 368 zwrot przedmiotu darowizny następował według przepisów o niesłusznym zbogaceniu ${ }^{80}$ (art. 123127 k.z.). Zwrot przedmiotu darowizny miał nastąpić w naturze. Gdyby się tego

73 Art. 80 projektu wstępnego: „Odwołanie uskutecznia się przez oświadczenie wobec obdarowanego. W razie odwołania można żądać zwrotu podarunku podług przepisów o zwrocie świadczenia nienależnego. Obdarzony odpowiada jako posiadacz w złej wierze, od chwili popełnienia uchybienia".

${ }^{74}$ R. Longchamps de Berier, op. cit., s. 115-116.

${ }^{75}$ L. Domański, op. cit., s. 173.

76 R. Longchamps de Berier, op. cit., s. 115.

${ }^{77}$ L. Domański, op. cit., s. 173; J. Korzonek, I. Rosenblüth, op. cit., s. 943-944.

78 SN: „W razie odwołania darowizny już wykonanej, obdarowany nie ma obowiązku wytaczać powództwa o ustalenie bezzasadności odwołania darowizny. Przeciwnie, darczyńca winien zapozywać obdarowanego o zwrot przedmiotu darowizny według przepisów o wydaniu niesłusznego zbogacenia (art. $368 \S 2$ k.z.), obdarowany zaś może w drodze zarzutu podnieść bezzasadność odwołania darowizny dla braku ku temu przesłanek, przy czym sąd procesowy musi rozpoznać powyższy zarzut” (SN z dnia 17 marca 1938, C II 2404/37, „Nowy Kodeks Zobowiązań” 1939, nr 10, s. 36), [za:] F. Zoll, op. cit., s. 331.

${ }^{79}$ R. Longchamps de Berier, op. cit., s. 115; L. Domański, op. cit., s. 116.

${ }^{80}$ Szerzej A. Ohanowicz, Niestuszne wzbogacenie, Warszawa 1956. 
nie udało uskutecznić, następowało przysądzenie równowartości w pieniądzach (art. 123 k.z.). W przypadku gdy obdarowany nie miał już przedmiotu darowizny, ale miał jego wartość, zobowiązany był, w razie odwołania, do wydania odwołującemu wartości (art. 124 k.z.). Jeżeli obdarowany przekazał przedmiot darowizny osobie trzeciej, wtedy w razie odwołania darowizny osoba trzecia zobowiązana była do zwrotu przedmiotu darowizny odwołującemu (art. 125 k.z.). $\mathrm{Z}$ kolei w przypadku dokonania przez obdarowanego nakładów na przedmiot darowizny, mógł on żądać zwrotu nakładów tylko do wysokości zwiększenia się wartości rzeczy lub zabrać je z powrotem, jeśli było to możliwe bez uszkodzenia rzeczy (art. 126 k.z.). Jeżeli obdarowany nie posiadał już przedmiotu darowizny ani jego wartości, to nie był zobowiązany do zwrotu. Gdyby jednak pozbycia dokonał w złej wierze albo wśród okoliczności, wśród których powinien się liczyć z obowiązkiem zwrotu, wtedy był do niego obowiązany. Ustawodawca uznał obdarowanego za będącego w złej wierze już od chwili popełnienia czynu uzasadniającego odwołanie z powodu niewdzięczności, bez względu na to, czy liczył się z odwołaniem czy nie. W związku z tym zbycie przedmiotu darowizny po popełnieniu czynu uzasadniającego odwołanie darowizny uważano za dokonane w złej wierze i nie zwalniało obdarowanego od obowiązku zwrotu wartości przedmiotu darowizny posiadanego w chwili popełnienia czynu (art. 127 k.z.) ${ }^{81}$. Samo żądanie zwrotu przedmiotu darowizny bez uprzedniego odwołania darowizny uważano za równoznaczne z odwołaniem darowizny, a wniesienie do sądu pozwu $\mathrm{z}$ takim żądaniem za równoznaczne $\mathrm{z}$ wykonaniem prawa odwołania ${ }^{82}$. W okresie po II wojnie światowej, zarówno w doktrynie, jak i judykaturze, kontrowersje wywołało zagadnienie odwołania darowizny nieruchomości. Główny przedmiot kontrowersji dotyczył kwestii skutków, jakie wywierało odwołanie darowizny nieruchomości, tj. czy były to tylko skutki obligacyjne, czy także rzeczowe ${ }^{83}$.

\section{Unieważnienie darowizny}

Przepisy art. 369 k.z. ${ }^{84}$, ostatniego w rozdziale dotyczącym odwołania darowizny w k.z., wzorowane były na przepisach art. 1803 ogólnego projektu rosyjskiego

${ }^{81}$ L. Domański, op. cit., s. 174-175; J. Korzonek, I. Rosenblüth, op. cit.; A. Neumark-Bądkowski, Darowizna wedlug Kodeksu zobowiazań, „Nowy Kodeks Zobowiązań” 1935, nr 33-34, s. 106 .

${ }^{82}$ L. Domański, op. cit., s. 174.

${ }^{83}$ Szerzej T. Dobaczewski, Forma i skutki prawne odwolania darowizny nieruchomości, „Nowe Prawo” 1957, nr 3, s. 102-103; zob. dalej uchwała SN z dnia 17 października 1963, III CO 51/63, OSPiKA 1965 IX, s. 56-57, oraz S. Breyer, glosa do uchwały SN z dnia 17 października 1963, III CO 51/63, OSPiKA 1965 IX, s. 57-59.

${ }^{84}$ Art. 369 k.z.: „§ 1. Przedstawiciel ustawowy osoby, pozbawionej zdolności do działań prawnych lub w niej ograniczonej, może domagać się sądownie unieważnienia darowizny, doko- 
kodeksu cywilnego $^{85}$ (wyd. 1910 r.). Według $§ 1$ art. 369 k.z. przedstawiciel ustawowy osoby pozbawionej zdolności do działań prawnych lub o zdolności ograniczonej mógł domagać się sądownie unieważnienia ${ }^{86}$ darowizny, dokonanej przez tę osobę przed pozbawieniem lub ograniczeniem jej zdolności do działań prawnych ${ }^{87}$. Uzasadnione to było domniemaniem, że już w chwili zdziałania darowizny istniały powody, dla których później darczyńca został ubezwłasnowolniony ${ }^{88}$. Przedstawiciel ustawowy mógł wystąpić z pozwem o unieważnienie darowizny z powodu nadmiernej wartości darowanego przedmiotu i braku poważnych pobudek moralnych. Nadmierna wartość darowizny zachodziła wtedy, gdy wyczerpywała w znacznej części majątek darczyńcy i była niewspółmierna do pobudek darczyńcy. Zatem sąd ustalając nadmierność darowizny, powinien ocenić wartość darowizny, pobudki moralne jej zdziałania przez darczyńcę, a więc położenie majątkowe darczyńcy, okoliczności darowizny oraz wagę i charakter pobudek, którymi kierował się darczyńca $^{89}$.

Według § 2 art. 369 k.z. unieważnienia darowizny nie można było dochodzić po upływie dwóch lat od chwili jej wykonania. Termin ten biegł od momentu jej całkowitego wykonania, a więc jeśli darowiznę wykonano częściowo, to termin biegł od chwili, kiedy ostatnia część świadczenia została spełniona ${ }^{90}$. Termin z $§ 2$ art. 369 k.z. nie ulegał zawieszeniu ani przerwaniu w przypadkach przewidzianych w art. 277-280 k.z. odnoszących się do terminów przedawnienia. Wyjątkiem było zawieszenie wymiaru sprawiedliwości albo działanie siły wyższej, jako uniemożliwiających wniesienie pozwu we właściwym terminie (art. $277 \S 4$ k.z.) ${ }^{91}$.

$\mathrm{Z}$ brzmienia art. $369 \S 2$ k.z. wynika, że jeżeli dochodzenie unieważnienia musiało nastąpić przed upływem dwóch lat od wykonania darowizny, to ubezwłasnowolnienie musiało nastąpić jeszcze wcześniej ${ }^{92}$. W takim przypadku oraz

nanej przez tę osobę przed pozbawieniem jej zdolności do działań prawnych lub ograniczeniem tej zdolności, o ile darowizna, ze względu na wartość darowanego przedmiotu i brak poważnych pobudek moralnych, jest nadmierna.

$\S 2$. Unieważnienia darowizny nie można dochodzić sądownie po upływie dwóch lat od chwili jej wykonania".

85 Art. 1803 ogólnego projektu rosyjskiego kodeksu cywilnego: „Opiekun osoby, uznanej za niezdolną do działań prawnych z powodu marnotrawstwa, ma prawo żądać uchylenia darowizny, dokonanej przez tę osobę przed uznaniem jej za niezdolną, jeżeli darowizna ze względu na wartość darowanego mienia i brak poważnych pobudek moralnych jest nadmierna. Powództwo o uchylenie takiej darowizny może być wytyczone w ciągu dwóch lat od czasu dokonania darowizny”, [za:] L. Domański, op. cit., s. 175.

${ }^{86}$ Warto zwrócić uwagę na różnice pomiędzy unieważnieniem a odwołaniem darowizny szerzej J. Namitkiewicz, op. cit., s. 95-96.

${ }^{87}$ L. Domański, op. cit., s. 175.

${ }^{88}$ R. Longchamps de Berier, op. cit., s. 116.

89 J. Namitkiewicz, op. cit., s. 95-96.

90 J. Korzonek, I. Rosenblüth, op. cit., s. 947.

${ }^{91}$ L. Domański, op. cit., s. 176.

92 R. Longchamps de Berier, op. cit., s. 116. 
w przypadku ustanowienia dla darczyńcy przedstawiciela ustawowego po upływie dwóch lat od chwili wykonania darowizny prawo żądania unieważnienia darowizny na podstawie art. 369 k.z. nie powstawało ${ }^{93}$.

Jeżeli sąd na żądanie przedstawiciela ustawowego darczyńcy stwierdził prawomocnym wyrokiem unieważnienie darowizny, przedmiot darowizny ulegał zwrotowi na podstawie art. 130 k.z. ${ }^{94}$, a obowiązek zwrotu ulegał dwudziestoletniemu przedawnieniu zgodnie $\mathrm{z}$ art. 281 k.z. ${ }^{95}$

Warto wspomnieć, że w projekcie głównym zawarte jeszcze były w art. 8185 przepisy o zwalczaniu darowizny przez wierzycieli, które nie znalazły się w rozdziale dotyczącym odwołania darowizny ${ }^{96}$.

\section{Zakończenie}

Przepisy dotyczące odwołania darowizny znajdujące się w polskim kodeksie zobowiązań, podobnie jak przepisy całego kodeksu zobowiązań, były syntezą kodeksów pozaborowych oraz nowszych kodeksów cywilnych i projektów. Analizując przepisy poszczególnych artykułów dotyczących odwołania darowizny w polskim kodeksie zobowiązań, można zauważyć przede wszystkim wpływ przepisów BGB oraz szwajcarskiego prawa o zobowiązaniach. Widoczne jest to w rozwiązaniach przyjętych zwłaszcza $\mathrm{w}$ art. 364 k.z. dotyczącym odwołania darowizny jeszcze niewykonanej ( $\$ 519$ BGB oraz art. 250 ust. 2 szwajcarskiego kodeksu zobowiązań). Z kolei art. 365 k.z. wzorowany był na § 947 ABGB. Natomiast przykładem stworzenia przepisów będących swoistą kompilacją i udoskonaleniem dotychczasowych rozwiązań przyjętych w kodeksach pozaborowych oraz kodeksie cywilnym szwajcarskim są art. 366 oraz 367 k.z. dotyczące odwołania darowizny już wykonanej z powodu rażącej niewdzięczności. Można tu dostrzec wpływ zasady sprawiedliwości, będącej wyrazem przyjętych w k.z. postulatów uspołecznienia prawa zobowiązań. Przepisy art. 368 k.z. dotyczące formy odwołania darowizny oraz zwrotu przedmiotu darowizny utworzone zostały w wyniku syntezy dotychczasowych rozwiązań. Natomiast przepisy art. 369 k.z. stanowiące o unieważnieniu darowizny przez przedstawiciela ustawowego wzorowane były na art. 265 rosyjskiego projektu prawa o zobowiązaniach.

Z dostępnych orzeczeń Sądu Najwyższego można wywnioskować, że w praktyce główne problemy interpretacyjne budziły przede wszystkim przepisy art. 366

93 J. Korzonek, I. Rosenblüth, op. cit., s. 947.

94 Art. 130 k.z.: „Nieważność zobowiązania pociąga za sobą obowiązek zwrotu otrzymanego świadczenia, chyba że zobowiązanie po spełnieniu świadczenia stało się ważnem”.

95 Art. 281 k.z.: „Każda wierzytelność ulega przedawnieniu z upływem lat dwudziestu, jeżeli ustawa inaczej nie stanowi”.

${ }^{96}$ Szerzej L. Domański, op. cit., s. 176-178. 
k.z. stanowiące o odwołaniu darowizny z powodu rażącej niewdzięczności ${ }^{97}$ oraz przepisy art. 368 k.z. dotyczące odwołania darowizny nieruchomości.

\title{
Bibliografia
}

\author{
Źródła
}

\section{Akty prawne}

Rozporządzenie Prezydenta Rzeczypospolitej z dnia 27 października 1933 r. — Przepisy wprowadzające Kodeks zobowiązań (Dz.U. RP Nr 82, poz. 599).

\section{Orzeczenia}

Orzeczenie SN z dnia 6 września 1937 (C II 580/37, „Głos Adwokatów” 1938, z. 4, s. 131).

Orzeczenie SN z dnia 14 września 1937 (C II 651/37, „Nowy Kodeks Zobowiązań” 1938, s. 51), [za:] J. Namitkiewicz, Kodeks zobowiąań, Łódź 1949, s. 86.

Orzeczenie SN z dnia 14 grudnia 1937 (C II 1542/37, „Nowa Palestra” 1938, nr 6), [za:] F. Zoll, Zobowiąania w zarysie wedlug polskiego kodeksu zobowiazań, Warszawa 1948, s. 331.

Orzeczenie SN z dnia 21 grudnia 1937 (C II 1613/37, „Nowy Kodeks Zobowiązań” 1938, s. 161), [za:] J. Namitkiewicz, Kodeks zobowiazań, Łódź 1949, s. 88-89.

Orzeczenie SN z dnia 10 lutego 1938 (C II 2054/37, OSP 517/1938).

Orzeczenie SN z dnia 17 marca 1938 (C II 2404/37, „Nowy Kodeks Zobowiązań”1939, nr 10, s. 36), [za:] F. Zoll, Zobowiązania w zarysie wedlug polskiego kodeksu zobowiazań, Warszawa 1948, s. 331.

Orzeczenie SN z dnia 30 marca 1938 (C II 2544/37, „Przegląd Prawa i Administracji. Orzecznictwo" 1938, poz. 209).

Orzeczenie SN z dnia 21 stycznia 1948 (C I 773/47, „Państwo i Prawo” 1948, z. 5-6, s. 177).

Orzeczenie SN z dnia 2 marca 1948 (KrC 42/48, „Państwo i Prawo” 1948, z. 7, s. 136).

Uchwała SN z dnia 17 października 1963 (III CO 51/63, OSPiKA 1965 IX, s. 56-57).

\section{Literatura}

Breyer S., glosa do uchwały SN z dnia 17 października 1963, III CO 51/63, OSPiKA 1965 IX.

Dobaczewski T., Forma i skutki prawne odwołania darowizny nieruchomości, „Nowe Prawo” 1957, nr 3.

Domański L., Instytucje kodeksu zobowiąań. Komentarz teoretyczno-praktyczny. Część szczególna, Warszawa 1938.

${ }^{97}$ Uwagi na temat art. 366 k.z. zgłaszał Kazimierz Korzan. Dotyczyły one wyjaśnienia skutków rażącej niewdzięczności obdarowanego w wieku poniżej lat 18 z punktu widzenia jego poczytalności oraz ustalenia, czy i w jakich wypadkach rażąca niewdzięczność przedstawiciela ustawowego małoletniego daje podstawę darczyńcy do odwołania darowizny względem małoletniego - szerzej K. Korzan, Kilka uwag na temat wyktadni art. 366, „Nowe Prawo” 1962, nr 7-8, s. 1037-1041. 
Górnicki L., Prawo cywilne w pracach Komisji Kodyfikacyjnej Rzeczypospolitej Polskiej w latach 1919-1939, Wrocław 2000.

Górnicki L., Zasada uspołecznienia pewnych stosunków umownych w kodeksie zobowiazań z 1933 roku, [w:] Zasady prawne w dziejach prawa publicznego i prywatnego, red. M. Podkowski, Wrocław 2015, s. 153-169.

Korzan K., Kilka uwag na temat wyktadni art. 366, „Nowe Prawo” 1962, nr 7-8.

Korzonek J., Rosenblüth I., Kodeks zobowiazań. Komentarz, t. 1, Kraków 1936.

Longchamps de Berier R., Uzasadnienie projektu kodeksu zobowiazań, art. 294-369, t. 7, Warszawa 1937.

Namitkiewicz J., Kodeks zobowiazań, Łódź 1949.

Neumark-Bądkowski A., Darowizna wedtug Kodeksu zobowiązań, „Nowy Kodeks Zobowiązań” 1935, nr 33-34.

Ohanowicz A., Niestuszne wzbogacenie, Warszawa 1956.

Peiper L., Kodeks zobowiąań, Kraków 1934.

Till E., Longchamps de Berier R., Polskie prawo zobowiąań (część szczegółowa). Projekt wstępny z motywami, Lwów 1928.

Zoll F., Zobowiązania w zarysie wedlug polskiego kodeksu zobowiąań, Warszawa 1948.

\section{Cancellation of donation in the Polish Code of Obligations of 1933}

\section{Summary}

The article provides an analysis of the provisions of the Polish Code of Obligations of 1933 concerning cancellation of donation. The author discusses the provisions of Articles 364-369 of the Code, taking into account the impact of the various donation cancellation provisions included in regional codes and in other civil codes, i.e. the German Civil Code of 1896; Austrian Civil Code of 1811; Napoleonic Code of 1804; volume X, part 1 of the Russian Svod Zakonov Rossiyskoy Imperii of 1832; Swiss obligation law of 1911 and the draft Russian law of obligations of 1913.

He also compares the final versions of the articles with their versions from the draft law of obligations by Dr Ernest Till and Prof Roman Longchamps de Berier, who were members of the Codification Commission. In addition, the author cites selected judgements of the Supreme Court dealing with the matter.

Keywords: cancellation of donation, contract for donation, Code of Obligations, Codification Commission

\section{Der Widerruf einer Schenkung im polnischen Schuldrechtsbuch aus dem Jahre 1933}

\section{Zusammenfassung}

Der Aufsatz stellt die Beschlüsse des polnischen Schuldrechtsbuches aus dem Jahre 1933 betreffend den Widerruf einer Schenkung dar. Besprochen wurden daher die Vorschriften der Artikel 364-369 dieses Gesetzbuches. Die Bestimmungen der einzelnen Artikel betreffend diese Institution wurden unter Berücksichtigung des Einflusses der einzelnen Vorschriften betreffend den Widerruf einer Schenkung, die in den Gesetzbüchern der Teilungsgebiete und in anderen Zivilgesetzbüchern, d.h. im deutschen Bürgerlichen Gesetzbuch (BGB) aus dem Jahre 1896, im österreichischen Allge- 
meinen Bürgerlichen Gesetzbuch (ABGB) aus dem Jahre 1811, im Napoleons Code civil aus dem Jahre 1804, im Buch 10 Teil I des russischen Swod Zakonow Rossijskoj Imperii aus dem Jahre 1832 sowie dem schweizerischen Obligationsrecht in der Fassung von 1911 und im Entwurf des russischen Verpflichtungsrechtes aus dem Jahre 1913 analysiert.

Der letzte Wortlaut der einzelnen Artikel wurde auch mit ihrer Formulierung im einführenden Entwurf des Schuldrechtes von Prof. Dr. Ernst Till und Prof. Dr. Roman Longchamps de Berier, den Mitgliedern der Kodifikationskommission verglichen. Ergänzend zu der Analyse der einzelnen Vorschriften über den Widerruf einer Schenkung nannte der Autor auch ausgewählte Beschlüsse des Obersten Gerichtes aus diesem Bereich.

Schlüsselworte: Widerruf der Schenkung, Schenkungsvertrag, Schuldrechtsbuch, Kodifikationskommission 